\title{
The impact of capital structure on the market value of energy sector companies on the example of companies from Poland
}

\author{
Robert Ranosz ${ }^{1, *}$ \\ ${ }^{1} \mathrm{AGH}$ University of Science and Technology, Faculty of Mining and Geoengineering, \\ al. A. Mickiewicza 30, 30-059 Kraków, Poland
}

\begin{abstract}
The focus of this article is to analyse the impact of capital structure on the value of energy sector companies listed on the Warsaw Stock Exchange. The proposed study will cover the last four years, i.e. 2014-2017, in quarterly terms. In addition to the mentioned capital structure parameter, the analysis also covers such indicators as return on equity (ROE) and return on assets (ROA). The study will use multiple regression based on the deltas of the respective parameters describing their changes quarter-to-quarter. The author of this publication assumes that capital structure may have an impact on the value of energy sector companies. The assumption is based on the market phenomenon whereby capital structure seems to reflect to a certain extent the risk incurred by investors: on the one hand, the higher the share of borrowed capital in financing an enterprise's operations, the higher the risk; on the other hand, the higher the proportion of equity in the financing of corporate operations, the lower the chance for dividends to be paid to investors in the respective companies. Investigating the mentioned phenomenon will make it possible, to a certain extent, to answer the question of whether Polish investors are more willing to accept investment risk in exchange for a higher return on investment or whether they would rather limit investment risk and yield lower profit from the capital invested in a given enterprise.
\end{abstract}

\section{Introduction}

Corporate value can be determined in various ways [1,2,3]. One of them is the expression of a company's market value in its stock prices. This measurement seems the most accurate due to the fact that the market itself, i.e. the investors, determine how much they are prepared to pay for shares in a specific entity. Thus, the market value of a given enterprise is determined by the market and its investors. The impact on decisions made by them may vary and it is difficult to define the factors and variables considered by investors. This article focuses on leverage, i.e. the proportion of borrowed funds in corporate financing and also on such indicators as return on assets (ROA) and return on equity (ROE). The selection of these indicators was based on the following premises. In the case

\footnotetext{
*Corresponding author: rranosz@agh.edu.pl
} 
of the first factor, i.e. leverage, it was stated that this is one of the tools with which investors are able to determine investment risk associated with investing in a given entity; the higher the indicator, the greater the risk. This is associated with the fact that a higher debt rate may increase the probability that an enterprise finds itself in a difficult financial situation [4]. There are numerous borrowed capital sources, and the subject has already been discussed [5]. It should also be mentioned that the extent of relying on borrowed capital differs depending on the sector or company [6]. The selection of the remaining two indicators is related to the fact that investors who buy a specific company's stock expect profits. Therefore, two aspects were considered which may draw the attention of potential investors, i.e. risk and potential profit from a given investment.

The paper discusses 8 companies operating in the energy sector (producing and trading electricity), which are representative of the industry, and are listed on the Warsaw Stock Exchange (GPW). The discussed companies are included in the portfolios of such indices as WIG20, WIG-Energia (energy) or WIG-Górnictwo (mining). Given the fact that the paper deals with Polish energy sector companies, it was essential to include companies relying in their operations on hard coal or brown coal in the main part of the analysis. Due to this, not all the companies whose main business line is trading only electricity were taken into consideration. The study presents the market values of the companies and the share of foreign capital in them.

\section{The capital structure and value of Polish energy sector companies}

On the Polish market (the Warsaw Stock Exchange, GPW) nine companies producing electricity are listed. In terms of value, PGE Polska Grupa Energetyczna SA is the largest, with its value oscillating around PLN 20 bn. The smallest of them is Elektrociepłownia Będzin SA, with a market value of around PLN $70 \mathrm{~m}$. Figure 1 presents the market value of all energy sector companies listed on GPW. It should be mentioned that there is one company from this sector listed on GPW which is not a Polish-capital company, i.e. the Lithuanian Inter Rao Lietuva AB.

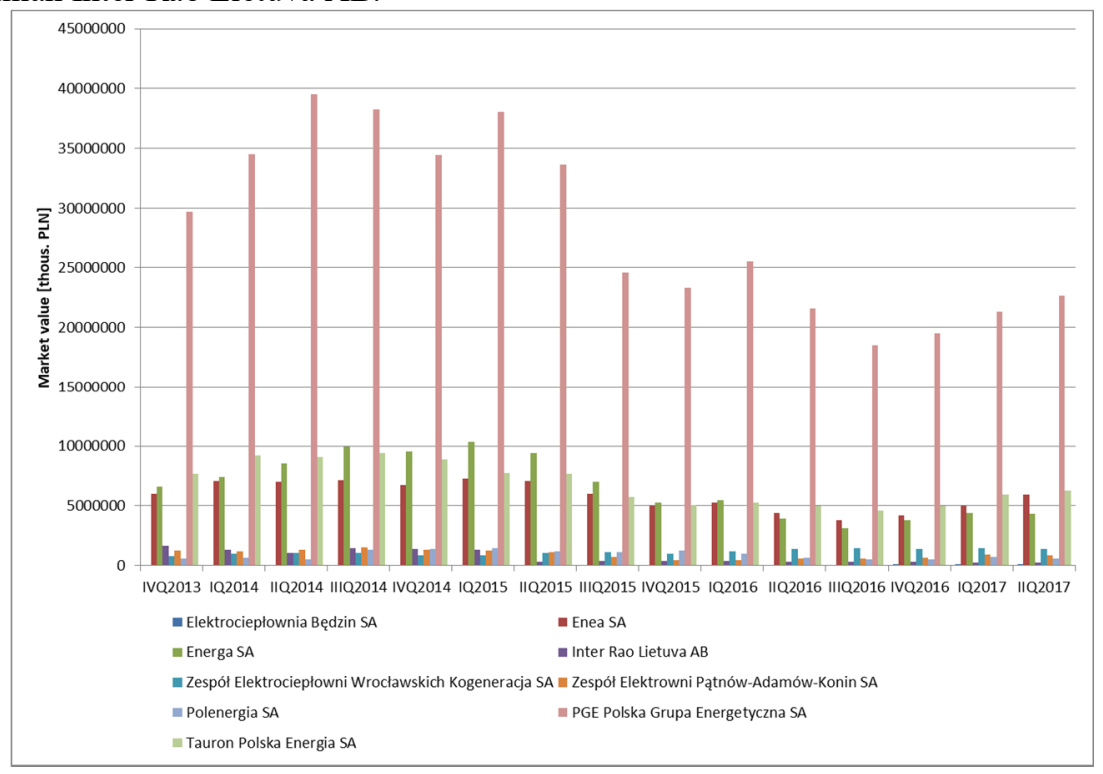

Fig. 1. The market value of the respective Polish energy sector enterprises in the respective quarters 
The value of companies presented in Figure 1 changes over time. To better illustrate the changes, their relative value is presented, with Q4 of 2013 as the point of departure (Figure 2). As shown in Figure 2, some companies from the energy sector decreased and others gained in value. A number of factors could contribute to such results. This article focuses on such variables as capital structure, return on assets and return on equity.

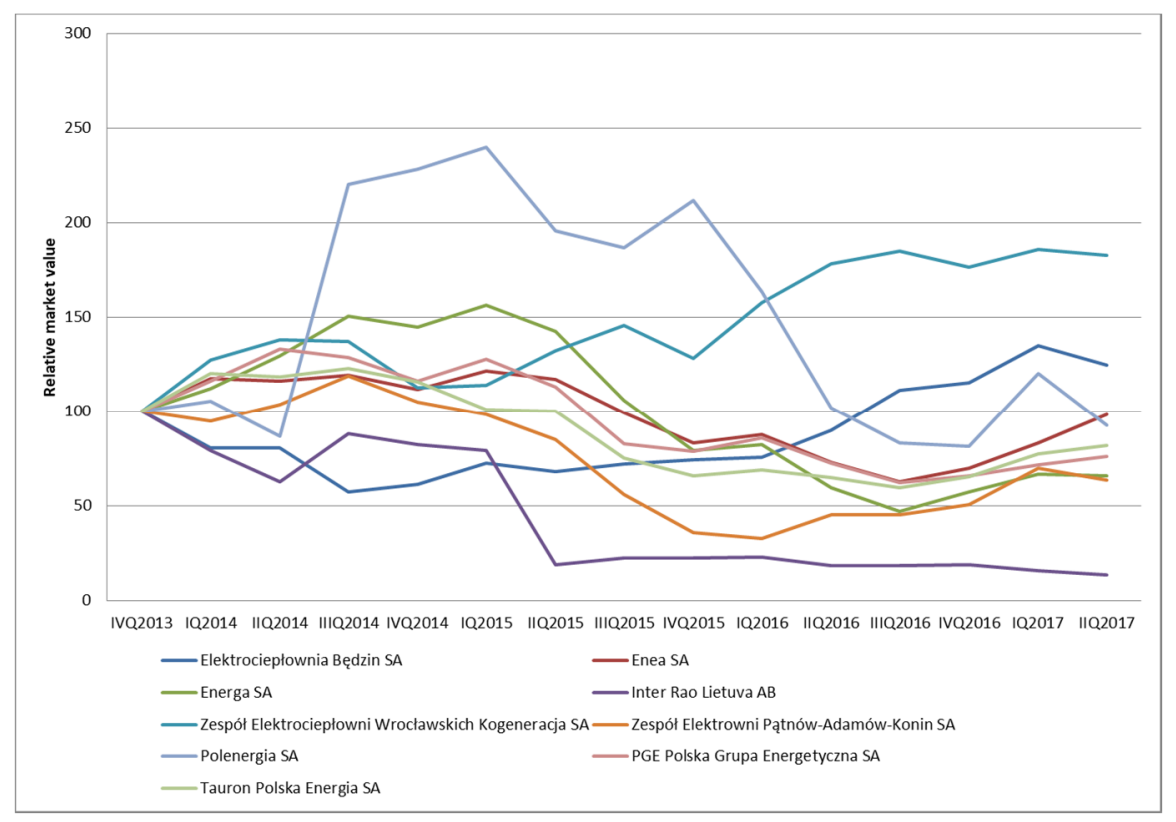

Fig. 2. Relative market value of energy sector companies (value from Q4 $2013=100 \%$ )

The analysis of changes in the value of energy sector companies demonstrates that the highest increase in value was recorded by Zespół Elektrociepłowni Wrocławskich Kogeneracja SA (a rise of $82 \%$ ) and Elektrociepłownia Będzin SA (a growth of 24\%). When analysing the two enterprises, it should also be emphasised that these are the smallest among the GPW energy sector companies. The greatest loss in value was observed for Inter Rao Lietuva $\mathrm{AB}$, which is also one of the smallest on the market. As far as larger companies are concerned, their market value was not subject to any major fluctuations. Based on the analysis of Figure 2, it can be confirmed that the smallest companies report the most considerable stock price fluctuations.

Another aspect under analysis in the context of energy sector companies was their capital structure. Figure 3 shows the percentage of borrowed capital in financing these enterprises' operations. 


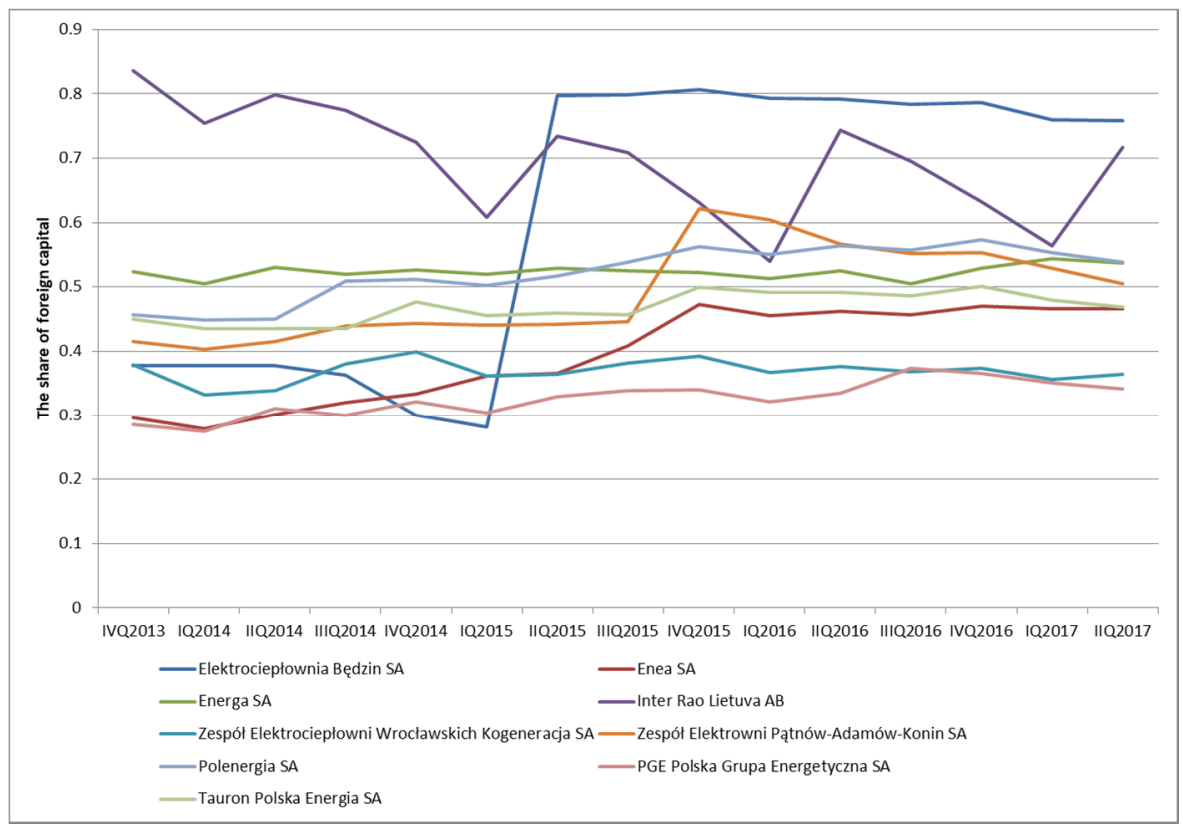

Fig. 3. The percentage of borrowed capital in financing the operations of energy sector companies

In terms of capital structure, there is one entity which reported exceptional values, i.e. Elektrociepłownia Będzin SA. As shown in Figure 3, in Q1 2015 the company made significant investments, funded primarily with borrowed capital. This investment could be one of the reasons for an increase in the company's market value, as shown in Figure 2. Another aspect to be considered is the extent of using borrowed capital. Two companies are distinguished here, i.e. the previously mentioned Elektrociepłownia Będzin SA with a borrowed capital share exceeding $70 \%$ and Inter Rao Lietuva AB, with a similar level of borrowed capital.

\section{Determinants of the capital structure and the market value of energy sector companies}

The value of companies listed on GPW depends on a number of factors. For the present article the author selected three indicators: leverage, return on equity (ROE) and return on assets (ROA). It should be emphasised that the analysis did not take into consideration absolute values but changes in the values of particular figures. Thus, the article analysed the impact of the variability of the respective parameters on the variability of values obtained by specific energy sector enterprises. The study covered 8 energy companies listed on GPW; Table 1 shows variables used for multiple regression analysis. All the financial data were found on the website notoria.pl [7]. The objective of the analysis was to investigate whether the variability of the value of Polish enterprises from the sector in question is influenced by the variability of their capital structure. The analysis also considered the variability of ROE and ROA. 
Table 1. Description of variables used to perform multiple regression

\begin{tabular}{|c|c|c|}
\hline var. 1 & CORPORATE MARKET VALUE & Elektrociepłownia Będzin SA \\
\hline var. 2 & CORPORATE MARKET VALUE & Enea SA \\
\hline var. 3 & CORPORATE MARKET VALUE & Energa SA \\
\hline var. 4 & CORPORATE MARKET VALUE & Inter Rao Lietuva $\mathrm{AB}$ \\
\hline var. 5 & CORPORATE MARKET VALUE & $\begin{array}{c}\text { Zespół Elektrociepłowni Wrocławskich } \\
\text { Kogeneracja SA }\end{array}$ \\
\hline var. 6 & CORPORATE MARKET VALUE & Zespół Elektrowni Pątnów-Adamów-Konin SA \\
\hline var. 7 & CORPORATE MARKET VALUE & PGE Polska Grupa Energetyczna SA \\
\hline var. 8 & CORPORATE MARKET VALUE & Tauron Polska Energia SA \\
\hline var. 9 & LEVERAGE & Elektrociepłownia Będzin SA \\
\hline var. 10 & LEVERAGE & Enea SA \\
\hline var. 11 & LEVERAGE & Energa SA \\
\hline var. 12 & LEVERAGE & Inter Rao Lietuva $\mathrm{AB}$ \\
\hline var. 13 & LEVERAGE & $\begin{array}{l}\text { Zespół Elektrociepłowni Wrocławskich } \\
\text { Kogeneracja SA }\end{array}$ \\
\hline var. 14 & LEVERAGE & Zespół Elektrowni Pątnów-Adamów-Konin SA \\
\hline var. 15 & LEVERAGE & PGE Polska Grupa Energetyczna SA \\
\hline var. 16 & LEVERAGE & Tauron Polska Energia SA \\
\hline var. 17 & ROE & Elektrociepłownia Będzin SA \\
\hline var. 18 & ROE & Enea SA \\
\hline var. 19 & ROE & Energa SA \\
\hline var. 20 & ROE & Inter Rao Lietuva $\mathrm{AB}$ \\
\hline var. 21 & ROE & $\begin{array}{l}\text { Zespół Elektrociepłowni Wrocławskich } \\
\text { Kogeneracja SA }\end{array}$ \\
\hline var. 22 & ROE & Zespół Elektrowni Pątnów-Adamów-Konin SA \\
\hline var. 23 & ROE & PGE Polska Grupa Energetyczna SA \\
\hline var. 24 & ROE & Tauron Polska Energia SA \\
\hline var. 25 & ROA & Elektrociepłownia Będzin SA \\
\hline var. 26 & ROA & Enea SA \\
\hline var. 27 & ROA & Energa SA \\
\hline var. 28 & ROA & Inter Rao Lietuva $\mathrm{AB}$ \\
\hline var. 29 & ROA & $\begin{array}{c}\text { Zespół Elektrociepłowni Wrocławskich } \\
\text { Kogeneracja SA }\end{array}$ \\
\hline var. 30 & ROA & Zespół Elektrowni Pątnów-Adamów-Konin SA \\
\hline var. 31 & ROA & PGE Polska Grupa Energetyczna SA \\
\hline var. 32 & ROA & Tauron Polska Energia SA \\
\hline
\end{tabular}

Source: self-designed 
The first of the analysed companies was Elektrociepłownia Będzin SA. The results of multiple regression analysis are shown in Table 2.

Table 2. Multiple regression results for Elektrociepłownia Będzin SA.

\begin{tabular}{|c|c|c|c|c|c|c|}
\hline & \multicolumn{5}{|c|}{$\begin{array}{c}\text { Summary of the regression of dependent variable: var. 1 (Sheet 33) } \\
\mathrm{R}=.89582180\end{array} \mathrm{R}^{\wedge} 2=.80249670$ Adjusted R2=.67905714 } \\
& \multicolumn{5}{|c|}{$\mathrm{F}(5.8)=6.5011$} & $\mathrm{p}<.01061$ standard estimation error: .08420 \\
\cline { 2 - 7 } & $\mathrm{b}^{*}$ & $\begin{array}{c}\text { Standard } \\
\text { error }\end{array}$ & $\mathrm{b}$ & $\begin{array}{c}\text { Standard } \\
\text { error }\end{array}$ & $\mathrm{t}(8)$ & $\mathrm{p}$ \\
\hline Absolute term & & & 0.032194 & 0.025590 & 1.25804 & 0.243852 \\
\hline var. 28 & 0.830892 & 0.163993 & 0.096785 & 0.019102 & 5.06664 & 0.000969 \\
\hline var. 9 & -0.767467 & 0.235225 & -0.227921 & 0.069857 & -3.26270 & 0.011481 \\
\hline var. 23 & -0.946865 & 0.290100 & -0.192499 & 0.058978 & -3.26393 & 0.011460 \\
\hline var. 12 & -0.577206 & 0.234137 & -0.513726 & 0.208388 & -2.46524 & 0.038999 \\
\hline var. 32 & 0.306576 & 0.175906 & 0.054287 & 0.031149 & 1.74284 & 0.119528 \\
\hline
\end{tabular}

As shown in the study, selected variables demonstrated in Table 1 are significant for shaping the market value of the enterprise. These were variables with $\mathrm{p}<0.05$, i.e. Var. 28 (ROA Inter Rao Lietuva AB), Var. 9 (LEVERAGE Elektrociepłownia Będzin SA), Var. 23 (ROE PGE Polska Grupa Energetyczna SA) and Var. 12 (LEVERAGE Inter Rao Lietuva $A B)$. On the basis of the obtained results it can be concluded that the variability of the market value of the said enterprise, in addition to the variability of its capital structure, is influenced by the leverage of Inter Rao Lietuva AB. It is worth pointing out that the two enterprises are the smallest among the companies listed on GPW in terms of value and are characterised by the highest share of borrowed capital (high financial risk). ROE of PGE Polska Grupa Energetyczna SA, the largest Polish energy company, is also crucial for the discussed company. In conclusion, it was demonstrated that the enterprise's capital structure was one of the determinants of the variability of its market value.

The next investigated company was Enea SA. The results of multiple regression analysis are shown in Table 3.

Table 3. Multiple regression results for Enea SA.

\begin{tabular}{|c|c|c|c|c|c|c|}
\hline \multirow{2}{*}{} & \multicolumn{5}{|c|}{$\begin{array}{r}\text { Summary of the regression of dependent variable: var. 2 (Sheet 33) } \\
\mathrm{R}=.95100881\end{array} \mathrm{R}^{\wedge} 2=.90441775$ Adjusted $\mathrm{R} 2=.79290512$} \\
& \multicolumn{5}{|c|}{$\mathrm{F}(7.6)=8.1105$} & $\mathrm{p}<.01048$ standard estimation error: .06029 \\
\cline { 2 - 7 } & $\mathrm{b}^{*}$ & $\begin{array}{c}\text { Standard } \\
\text { error }\end{array}$ & $\mathrm{b}$ & $\begin{array}{c}\text { Standard } \\
\text { error }\end{array}$ & $\mathrm{t}(6)$ & $\mathrm{p}$ \\
\hline Absolute term & & & 0.07681 & 0.022525 & 3.40987 & 0.014321 \\
\hline var. 15 & -0.538180 & 0.146716 & -1.10932 & 0.302417 & -3.66818 & 0.010477 \\
\hline var. 10 & -0.464105 & 0.137679 & -1.02496 & 0.304059 & -3.37093 & 0.015025 \\
\hline var. 19 & 0.151258 & 0.142822 & 0.03187 & 0.030089 & 1.05907 & 0.330330 \\
\hline var. 11 & 0.267161 & 0.140013 & 1.24566 & 0.652822 & 1.90811 & 0.104982 \\
\hline var. 31 & 0.749823 & 0.235681 & 0.13724 & 0.043138 & 3.18152 & 0.019039 \\
\hline var. 9 & 0.467130 & 0.191233 & 0.12366 & 0.050625 & 2.44272 & 0.050285 \\
\hline var. 12 & 0.189482 & 0.174795 & 0.15033 & 0.138678 & 1.08402 & 0.319980 \\
\hline
\end{tabular}


Both for the previously analysed company and for Enea SA the variability of capital structure (Var. 10) had an impact on the variability of the analysed enterprise's value. In addition to the mentioned factor, the following variables were of significance: Var. 15 (Leverage PGE Polska Grupa Energetyczna SA) and Var. 31 (Leverage PGE Polska Grupa Energetyczna SA). In line with the analysis carried out, other factors were not taken into consideration. Therefore, it may be stated that the variability of Enea SA's value does not depend solely on the changeability of its capital structure but also on the variability of return on assets and of the capital structure of the largest Polish energy company listed on GPW.

The next company to undergo analysis was Energa SA. The results of multiple regression analysis are shown in Table 4.

Table 4. Multiple regression results for Energa SA.

\begin{tabular}{|c|c|c|c|c|c|c|}
\hline & \multicolumn{5}{|c|}{$\begin{array}{r}\text { Summary of the regression of dependent variable: var. 3 (Sheet 33) } \\
\mathrm{R}=.46314025\end{array}$} \\
& \multicolumn{5}{|c|}{$\mathrm{F}(1.12)=3.2769$} & $\mathrm{p}<.09536$ Standard estimation error: .16252 \\
\cline { 2 - 7 } & $\mathrm{b}^{*}$ & $\begin{array}{c}\text { Standard } \\
\text { error }\end{array}$ & $\mathrm{b}$ & $\begin{array}{c}\text { Standard } \\
\text { error }\end{array}$ & $\mathrm{t}(12)$ & $\mathrm{p}$ \\
\hline Absolute term & & & 0.016767 & 0.046663 & 0.359309 & 0.725607 \\
\hline var. 31 & 0.463140 & 0.255848 & 0.112727 & 0.062273 & 1.810213 & 0.095358 \\
\hline
\end{tabular}

In the case of this company no significant variables (among the analysed variables) were shown with a major impact on the value variability of the enterprise listed on GPW.

Inter Rao Lietuva $\mathrm{AB}$ was investigated next. The results of multiple regression analysis are shown in Table 5.

Table 5. Multiple regression results for Inter Rao Lietuva AB

\begin{tabular}{|c|c|c|c|c|c|c|}
\hline & \multicolumn{5}{|c|}{$\begin{array}{c}\text { Summary of the regression of dependent variable: var. 4 (Sheet 33) } \\
\mathrm{R}=.90708896\end{array} \mathrm{R}^{\wedge} 2=.82281038$ Adjusted $\mathrm{R} 2=.76965350$} \\
& \multicolumn{5}{|c|}{$\mathrm{F}(3.10)=15.479 \mathrm{p}<.00044$ Standard estimation error: .12273 } \\
\cline { 2 - 7 } & $\mathrm{b}^{*}$ & $\begin{array}{c}\text { Standard } \\
\text { error }\end{array}$ & $\mathrm{b}$ & $\begin{array}{c}\text { Standard } \\
\text { error }\end{array}$ & $\mathrm{t}(10)$ & $\mathrm{p}$ \\
\hline Absolute term & & & -0.126231 & 0.042232 & -2.98899 & 0.013597 \\
\hline var. 9 & -0.654309 & 0.136168 & -0.334342 & 0.069580 & -4.80515 & 0.000718 \\
\hline var. 20 & -0.455051 & 0.139754 & -0.091891 & 0.028221 & -3.25609 & 0.008631 \\
\hline var. 10 & 0.357486 & 0.138666 & 1.523899 & 0.591107 & 2.57804 & 0.027508 \\
\hline
\end{tabular}

The analysed company is the only energy company listed on GPW without Polish capital. As shown in the study, the variability of Inter Rao Lietuva AB's value depends, among other factors, on the variability of its return on equity (Var. 20), with the remaining factors having an impact on the variability of its value: Var. 9 (Leverage Elektrociepłownia Będzin) and Var. 10 (Leverage Enea SA).

The following analysed enterprise was Zespół Elektrociepłowni Wrocławskich Kogeneracja SA. The results of multiple regression analysis are shown in Table 6. 
Table 6. Multiple regression results for Zespół Elektrociepłowni Wrocławskich Kogeneracja SA.

\begin{tabular}{|c|c|c|c|c|c|c|}
\hline & \multicolumn{5}{|c|}{$\begin{array}{c}\text { Summary of the regression of dependent variable: var. 5 (Sheet 33) } \\
\mathrm{R}=.87353873\end{array} \mathrm{R}^{\wedge} 2=.76306991$ Adjusted $\mathrm{R} 2=.61498861$} \\
& \multicolumn{5}{|c|}{$\mathrm{F}(5.8)=5.1530$} & $\mathrm{p}<.02076$ Standard estimation error: .07748 \\
\cline { 2 - 8 } & $\mathrm{b}^{*}$ & $\begin{array}{c}\text { Standard } \\
\text { error }\end{array}$ & $\mathrm{b}$ & $\begin{array}{c}\text { Standard } \\
\text { error }\end{array}$ & $\mathrm{t}(8)$ & $\mathrm{p}$ \\
\hline Absolute term & & & 0.06853 & 0.022331 & 3.06886 & 0.015375 \\
\hline var. 16 & -0.4308 & 0.27705 & -1.24158 & 0.798398 & -1.55509 & 0.158534 \\
\hline var. 27 & -21.0408 & 17.11621 & -4.23265 & 3.443171 & -1.22929 & 0.253891 \\
\hline var. 19 & 20.6990 & 17.10828 & 4.11027 & 3.397249 & 1.20988 & 0.260859 \\
\hline var. 29 & -0.3742 & 0.22325 & -0.07922 & 0.047262 & -1.67619 & 0.132227 \\
\hline var. 13 & -0.2875 & 0.21878 & -0.55727 & 0.424033 & -1.31423 & 0.225199 \\
\hline
\end{tabular}

Similarly to Energa SA, also in this case no significant variables were found to influence the variability of the analysed company's value, except for the absolute term.

The next enterprise to undergo analysis was Zespół Elektrowni Pątnów-Adamów-Konin SA. The results of multiple regression analysis are shown in Table 7.

Table 7. Multiple regression results for Zespół Elektrowni Pątnów-Adamów-Konin SA.

\begin{tabular}{|c|c|c|c|c|c|c|}
\hline & \multicolumn{5}{|c|}{$\begin{array}{c}\text { Summary of the regression of dependent variable: var. 6 (Sheet 33) } \\
\mathrm{R}=.96888604 \mathrm{R}^{\wedge} 2=.93874016\end{array}$ Adjusted $\mathrm{R} 2=.84072442$} \\
& \multicolumn{5}{|c|}{$\mathrm{F}(8.5)=9.5774 \mathrm{p}<.01173$ Standard estimation error: .08758 } \\
\cline { 2 - 8 } & $\mathrm{b}^{*}$ & $\begin{array}{c}\text { Standard } \\
\text { error }\end{array}$ & $\mathrm{b}$ & $\begin{array}{c}\text { Standard } \\
\text { error }\end{array}$ & $\mathrm{t}(5)$ & $\mathrm{p}$ \\
\hline Absolute term & & & -0.14450 & 0.060666 & -2.38182 & 0.063023 \\
\hline var. 14 & -1.6821 & 0.384304 & -3.27222 & 0.747587 & -4.37704 & 0.007175 \\
\hline var. 11 & 1.0710 & 0.170556 & 8.27086 & 1.317175 & 6.27924 & 0.001505 \\
\hline var. 28 & -0.8090 & 0.151190 & -0.13914 & 0.026002 & -5.35102 & 0.003062 \\
\hline var. 22 & -1.8148 & 0.414012 & -0.01886 & 0.004303 & -4.38344 & 0.007132 \\
\hline var. 18 & 16.7441 & 8.988166 & 4.45790 & 2.392978 & 1.86291 & 0.121516 \\
\hline var. 16 & -0.3814 & 0.167177 & -1.93153 & 0.846600 & -2.28152 & 0.071402 \\
\hline var. 9 & -0.2276 & 0.114039 & -0.09981 & 0.050004 & -1.99601 & 0.102461 \\
\hline var. 26 & -16.3790 & 8.940117 & -4.46379 & 2.436464 & -1.83208 & 0.126429 \\
\hline
\end{tabular}

The analysis of the enterprise demonstrated that there are four variables to describe the variability of Zespół Elektrowni Pątnów-Adamów-Konin SA. Var. 14 (LEVERAGE Zespół Elektrowni Pątnów-Adamów-Konin SA), Var. 11 (LEVERAGE Energa SA), Var. 28 (ROA Inter Rao Lietuva AB) and Var. 22 (ROE Zespół Elektrowni Pątnów-AdamówKonin SA). Here it is possible to state that, among others, changes in the capital structure and the variability of return on equity of the analysed enterprise influence the variability of the studied enterprise's market value.

PGE Polska Grupa Energetyczna SA was analysed next. The results of multiple regression analysis are shown in Table 8. 
Table 8. Multiple regression analysis for PGE Polska Grupa Energetyczna SA

\begin{tabular}{|c|c|c|c|c|c|c|}
\hline & \multicolumn{6}{|c|}{$\begin{array}{c}\text { Summary of the regression of dependent variable: var. } 7 \text { (Sheet 33) } \\
R=.95949669 \mathrm{R}^{\wedge} 2=.92063390 \text { Adjusted } \mathrm{R} 2=.79364814 \\
\mathrm{~F}(8.5)=7.2499 \mathrm{p}<.02153 \text { Standard estimation error: .05948 }\end{array}$} \\
\hline & $b^{*}$ & $\begin{array}{c}\text { Standard } \\
\text { error }\end{array}$ & $\mathrm{b}$ & $\begin{array}{l}\text { Standard } \\
\text { error }\end{array}$ & $\mathrm{t}(5)$ & $\mathrm{p}$ \\
\hline Absolute term & & & -0.00287 & 0.018946 & -0.15139 & 0.885584 \\
\hline var. 13 & -1.05290 & 0.182469 & -2.13982 & 0.370836 & -5.77027 & 0.002197 \\
\hline var. 31 & 1.01830 & 0.229648 & 0.18421 & 0.041544 & 4.43417 & 0.006802 \\
\hline var. 11 & 0.77284 & 0.193252 & 3.56151 & 0.890568 & 3.99915 & 0.010332 \\
\hline var. 28 & -0.74850 & 0.177175 & -0.07681 & 0.018183 & -4.22460 & 0.008291 \\
\hline var. 12 & 0.58775 & 0.206182 & 0.46088 & 0.161676 & 2.85065 & 0.035796 \\
\hline var. 14 & 0.41416 & 0.179139 & 0.48075 & 0.207942 & 2.31195 & 0.068740 \\
\hline var. 9 & 0.33045 & 0.188258 & 0.08646 & 0.049257 & 1.75528 & 0.139569 \\
\hline var. 18 & 0.18336 & 0.168675 & 0.02913 & 0.026797 & 1.08707 & 0.326611 \\
\hline
\end{tabular}

The analysis showed that the variability of the market value of PGE Polska Grupa Energetyczna SA is influenced by 5 variables, including: Var. 13 (Leverage Zespół Elektrociepłowni Wrocławskich Kogeneracja SA), Var. 31 (ROA PGE Polska Grupa Energetyczna SA), Var. 11 (Leverage Energa SA), Var. 28 (ROA Inter Rao Lietuva AB) and Var. 12 (Leverage Inter Rao Lietuva AB).

The last of the analysed companies was Tauron Polska Energia SA. The results of multiple regression analysis are shown in Table 9.

Table 9. Multiple regression results for Tauron Polska Energia SA

\begin{tabular}{|c|c|c|c|c|c|c|}
\hline & \multicolumn{6}{|c|}{$\begin{array}{c}\text { Summary of the regression of dependent variable: var. } 8 \text { (Sheet 33) } \\
\mathrm{R}=.87806816 \mathrm{R}^{\wedge} 2=.77100369 \text { Adjusted } \mathrm{R} 2=.70230479 \\
\mathrm{~F}(3.10)=11.223 \mathrm{p}<.00153 \text { Standard estimation error: } .06766\end{array}$} \\
\hline & $b^{*}$ & $\begin{array}{c}\text { Standard } \\
\text { error }\end{array}$ & $\mathrm{b}$ & $\begin{array}{c}\text { Standard } \\
\text { error }\end{array}$ & $\mathrm{t}(10)$ & $\mathrm{p}$ \\
\hline Absolute term & & & 0.02026 & 0.022183 & 0.91331 & 0.382571 \\
\hline var. 10 & -0.707770 & 0.155935 & -1.46299 & 0.322323 & -4.53889 & 0.001077 \\
\hline var. 19 & 0.419104 & 0.156846 & 0.08264 & 0.030927 & 2.67208 & 0.023409 \\
\hline var. 18 & -0.404419 & 0.156841 & -0.06084 & 0.023596 & -2.57853 & 0.027486 \\
\hline
\end{tabular}

In the case of this company it was found that only three variables can have an impact on the variability of its value, such as Var. 10 (Leverage Enea SA), Var. 19 (ROE Energa SA), and Var. 18 (ROE Enea SA).

\section{Conclusions}

As demonstrated in the article, capital structure variability may have an impact on the variability of the value of specific enterprises from the energy sector in Poland. This was the case for three among the analysed companies: Elektrociepłownia Będzin SA, Enea SA and Zespół Elektrowni Pątnów-Adamów-Konin SA. In the remaining cases the proportion 
of borrowed capital was slightly less important. A lower impact of the variability of leverage may arise from the fact that in most cases the debt level is stable and the risk of the dividend not being paid out is minimal. It should also be emphasised that enterprises on the energy market in Poland function on a regulated market, which also may influence investors' perception of risk related to capital structure. The obtained results further make it possible to conclude that investors take numerous aspects into consideration when deciding on whether to buy or sell a company's stock. It is not surprising that the analysis of share purchases in a given entity also includes the operation of the remaining companies from the sector. On the basis of the study it can be concluded that investors pay greater attention to the risk (leverage) in the case of small enterprises (with a lower market value) than companies with a high value. In the case of large companies, investors are more likely to consider their profitability.

\section{References}

1. F. Poborský, Fundamentals of the Liquidation Method of Business Valuation, Procedia Economics and Finance 25, 386-393 (2015)

2. M. Grudziński, Wybrane problemy związane z wyceną przedsiębiorstw w Polsce, Studia I Prace Wydziału Nauk Ekonomicznych I Zarządzania 24, 39-49 (2011)

3. B. Prusak, Wycena przedsiębiorstw będących w trudnej sytuacji finansowej, Studia i Prace Kolegium Zarządzania i Finansów, zeszyty naukowy 153/2017, 121-141 (2017)

4. A. Rutkowski, Zarządzanie finansami (Finance management), Polskie Wydawnictwo Ekonomiczne, Warsaw (2007).

5. B. Kowal, R. Ranosz, W. Sobczyk, Sources of financing investments in the energy sector, Energy and fuels 2016, Kraków, 21-23 September (2016)

6. R. Rajan, L. Zingales, What do we know about capital structure? Some evidence from international data. J. Financ. 50, 1421-1460, (1995)

7. www.notoria.pl 